\title{
THE KOREAN QUESTION IN THE UNITED NATIONS*
}

\author{
By Chong-Ki ChoI
}

\section{Introduction}

The division of Korea, initially undertaken for the purpose of facilitating the surrender of the Japanese forces in the aftermath of the Second World War, has continued as a result of the inability of the Soviet Union and the United States to agree on conditions for unification. Division has been further hardened by the establishment of two contending Korean governments, another result of the great power rivalry ${ }^{1}$ which has deprived the Korean people of the opportunity for independence under a single government.

In 1946 when the Joint Commission of the American and Soviet Commands in Korea reached an impasse in its efforts to secure Korean independence, the United States decided to refer the problem to the United Nations. On September 17, 1947, the United States notified the Soviet Union in an official letter (AIBUR/85), of its plan to place the Korean question on the agenda of the second U. N. General Assembly and to include the matter of the independence of Korea on its agenda ${ }^{2}$.

The Soviet delegate, accusing the United States of breaking the Moscow Agreement ${ }^{3}$, opposed the U. S. proposal4. Despite the Soviet move, the General Committee of the General Assembly passed the U. S. proposal by a vote of twelve for and two against. The General Assembly then began its deliberations on the Korean question and adopted Resolution 112 (II) calling for the establishment of the U. N. Temporary Commission on Korea and general elections.

However, North Korea's refusal to grant the United Nations Temporary Commission on Korea "the right to travel, observe, and consult throughout Korea", soon led to a total impasse.

As a result, an election was held in South Korea and the Republic of Korea was established. On December 2, 1948, the United Nations recognized the Republic of Korea (ROK) as the only lawful sovereign in the Korean peninsula ${ }^{5}$. Almost immediately after the establishment of the Republic of Korea, another regime, the "Democratic People's Republic of Korea (DPRK)", was proclaimed in the northern zone under the aegis of the Soviet Union. The creation of the regime in the north was in direct violation of the principles outlined in the November 14, 1947 resolution of the U. N. General Assembly6.

The Republic of Korea applied for United Nations membership on January 19, 1949. The North Korean regime followed suit on February 10 of the same year. However, due to the negative note of the Soviet Union, no recommendation for

\footnotetext{
* This paper was prepared for delivery at the Sixth General Conference of the International Peace Research Association, Turku, Finland, August 15-18, 1975.

1 Leland M. Goodrich, The United Nations, New York, Thomas Y. Crowell, Co., 1959, pp. 53-54.

2 Redvers Opie and Associate, The Search for the Peace Settlements, Washington, D. C., The Brookings Institution, 1951, P. 306. Yearbook of U. N., 1947-48, p. 81.

Chong-Ki Choi, "The United Nations and Korea: Analysis of U. N. Debates on the Korean Question", The Korean Journal of International Studies (KJIS), vol. 1, no. 2 (Oct. 1970), p. 22.

3 Gulius W. Pratt, A History of United States Foreign Policy, Englewood Cliffs, Prentice-Hall, 1955,

4 P. 738 .

5 Resolution 195 (III) among 58 nations, in favor 48, against 6, absence 4, abstaining 3. YBUN, 1948-49,

6 Youngknok Koo, "The Conduct of Foreign Affairs", in Edward R. Wright, ed., Korean Politics in Transition, Seattle, Univ. of Washington Press, 1975, p.'221.
} 
admission of the ROK could be made to the General Assembly by the Security Council'. All subsequent efforts to obtain membership in the United Nations were rebuffed by the Soviet Union, the most recent being in $1975^{\circ}$. North Korea's application for admission to the United Nations was not even considered by the United Nations.

On June 25, 1950, when the North Korean regime unleashed an unprovoked invasion against the Republic of Korea, the United Nations not only helped the Republic to meet the resultant crisis ${ }^{9}$ but also made great contributions to solidifying the foundations of the Republic. For the past quarter century the United Nations has been deeply involved in the question of Korean reunification. This article will examine the manner in which the Korean question was handled by the U. N. General Assembly and analyse the unification policies of North and South Korea.

\section{The Korean War}

The new Republic of Korea was invaded by North Korea on June 25, 1950, before it had managed to solidify its national foundations ${ }^{10}$. War swept the country and continued for three years. In a resolution adopted on June 25, 1950, the U. N. Security Council "determined" that "the armed attack upon the Republic of Korea by forces from North Korea ... constitutes a breach of the peace." It called upon the North Korean authorities to "withdraw forthwith their armed forces to the Thirtyeighth Parallel." The Security Council also asked all U. N. members "to render every assistance to the United Nations in the execution of this resolution and to refrain from giving assistance to the North Korean authorities ${ }^{11}$." On July 7, the Security Council adopted resolution (S/1588) concerning the "creation and operation of the Unified Command."

On July 31, the Council also adopted resolution (S/1657) regarding "the relief and support of the civilian population of Korea." It should be noted that passage of such crucial Security Council resolutions were made possible by a Soviet boycott of the Council over the issue of Chinese representation. Had the Soviet Union been present, she would undoubtedly have vetoed them ${ }^{12}$.

In response to the June 27 Security Council resolution, sixteen U. N. member states sent troops to Korea, thus transforming the conflict into a struggle between the Democratic People's Republic of Korea (DPRK) and United Nations forces. This marked a significant milestone in the annals of the U. N., the first experiment in the use of collective military sanctions against a breach of international peace. The Korean action may not have been a military victory according to the text-

7 U. N., United Nations Repertory of Practice of United Nations Organs, vol. 1, New York, 1955, p. 169.

8 U. N., United Nations Repertory of Practice of United Nations Organs, Supp. no. 1, 1958, p. 87.

9 Security Council rescued Korea from emergence with the following resolution: The Requestment of the Cessation of Hostilities in Korea (S/1501) on June 25, 1950; The Creation and Operation of the Unified Command (S/1588) on July 25, 1950; The Relief and Support of the Civilian People of Korea (S/1655) on July 31, 1950. Fernand van Langenhave, La Crise du Système de SécuritéCollective des Nations Unies, 1946-1957, La Haye, Martinus Nijhoff, 1958, p. 76.

10 Security Council Official Records, vol. V, no. 15, pp. 1-2. U. N., Repertory of Practice of United Nations Organs, vol. V, 1955, pp. 176-177. YBUN, 1950, pp. 251-252. Glenn D. Paige, The Korean Decision, June 24-30, 1950, New York, The Free Press, 1968, p. 81.

11 Rosalyn Higgins, United Nations Peacekeeping 1946-1967, vol. 2, Asia, Oxford, Oxford Univ. Press,

12 B. C. Koh, "The United Nations and the Politics of Korean Reunification", Journal of Korean Affairs, vol. 3, no. 4 (Jan. 1974), p. 39. 
books, for the outcome in military terms was by no means conclusive; but the action was certainly a political victory for the purpose and principles of the Charter ${ }^{13}$.

On October 7, 1950, the General Assembly adopted Resolution 376 (V) providing for the establishment of the U. N. Commission for the Unification and Rehabilitation of Korea (UNCURK) ${ }^{14}$, which reaffirmed as the objectives of the U. N. in Korea, "the establishment of a unified, independent and democratic government of Korea."

By the time the Chinese People's Volunteers crossed the Yalu River in October, 1950, rescuing North Korea from the brink of defeat, the Soviet Union had returned to its permanent seat in the Security Council and was able to veto a draft resolution calling for the immediate withdrawal of Chinese forces ${ }^{15}$.

In accordance with the experience gained during the early stage of the Korean War, the U. N. General Assembly passed on November 30, 1950, "the Uniting for Peace Resolution ${ }^{16}$." The resolution made it possible for the General Assembly to obtain authority to recommend that member nations take collective measures including the use of military force, in case the Security Council was unable to fulfill its responsibility for the maintenance of international peace and security in the absence of unanimous agreement among its permanent members.

The newly prescribed powers of the General Assembly to make recommendations to members for collective measures were exercised for the first time with respect to the Chinese intervention in the Korean conflict. On February 1, 1951, the General Assembly adopted Resolution 498 (V) naming the People's Republic of China as an aggressor in Korea ${ }^{17}$. On May 18, 1951, the General Assembly adopted Resolution 500 (V) concerning the "additional measures to be employed to meet the aggression in Korea", and recommending that every state apply an embargo on the shipment of strategic materials to the People's Republic of China (PRC) and North Korea ${ }^{18}$.

In the meantime, the Korean War had reached a complete stalemate. In June 1951 a series of negotiations for an armistice began, and finally the U. N. and Communist sides managed to agree that wounded and sick prisoners of war would be exchanged in three weeks at Panmunjom. On April 18, the General Assembly adopted, with the unanimous support of the 60 member nations, Resolution 705 (VI) calling for the exchange of sick and wounded prisoners of war ${ }^{19}$.

When the war came to an inconclusive end on July 27, 1953, it was the Commander-in-Chief of the U. N. Command who signed the Armistice Agreement with the commanders of the North Korean People's Army and the Chinese People's Volunteers. Under the provision of Paragraph 60, Article IV of the

13 D. W. Bowett, United Nations Forces: A Legal Study of United Nations Practice, London, Stevens and Sons, 1964, p. 58.

14 YBUN, 1950, pp. 280-283.

15 U. S. Department of State, The Record on Korean Unification, 1943-1960, Department of State Publication 7084, Far Eastern Series 101 (Washington, D. C., 1960), pp. 109-110.

B. C. Koh, op. cit., p. 40.

16 Rosalyn Higgins, The Development of International Law through the Political Organs of United Nations, London, Oxford Univ. Press, 1963, p. 227.

Juraj Andrassy, "Uniting for Peace Resolution", American Journal of International Law (AJIL), vol. 50,

17 Higgins, United Nations Peacekeeping 1946-1967, op. cit., p. 168. Jerome A. Cohen and Hungdah Chiu, People's China and International Law, vol. 2, Princeton, Princeton Univ. Press, 1974, pp. $1324-1348$.

"Statement by Mr. Chou En-lai, Foreign Minister of the PRC, on General Assembly's Resolution of 1

Feb., 1951", in Denise Follit, ed., Documents in International, London, Oxford Univ. Press, 1954, pp. $548-551$

18 Lous B. Sohn, ed., Cases on United Nations Law, London, Stevens and Sons, Ltd., 1959, p. 526.

19 YBUN, 1953, pp. 113-114. 
Armistice Agreement, the military commanders of both sides were called upon to recommend to the governments of the countries concerned on both sides that, within three months after the Armistice Agreement was signed and became effective, the convening of a political conference on a higher level between both sides be held by representatives appointed respectively to settle through negotiating the question of the withdrawal of all foreign troops from Korea, and the peaceful settlement of the Korean question, among other items ${ }^{20}$. The General Assembly subsequently approved the "implementation of Paragraph 60 of the Korean Armistice Agreement" resolution 711 (VII) ${ }^{21}$, and a political conference was convened in Geneva lasting from April 26 to June 15, 1954, but no substantial progress was made 22 .

The focus of the Geneva Conference centered on the unification formula and the withdrawal of foreign troops. The U. N. side maintained that it had the right to supervise an all-Korean election. The Republic of Korea at first asserted that an election should be conducted only in North Korea in consideration of the legitimacy of the Republic, but later it accepted the U. N. view. In contrast, North Korea opposed U. N. supervision of the general elections and proposed the formation of an all-Korean commission, with equal representation from North and South Korea, to arrange for elections.

The primary responsibility for the Korean problem, after the close of the Geneva Conference on Korea, automatically reverted to the United Nations, where it has rested since $1947^{23}$.

\section{U. N. Debates on the Korean Question}

The United Nations General Assembly has reaffirmed, at each session since 1947, that "the objectives of the United Nations in Korea are to bring about, by peaceful means, the establishment of a unified, independent and democratic Korea under a representative form of government, and the full restoration of international peace and security in the area ${ }^{24}$." The Soviet Union and other Communist states have termed the resolution an action to "impose an unrealistic, one-sided resolution of the General Assembly25." As long as the Western bloc maintained majority power in the United Nations and the United States continued to fully exercise its influence over a majority of the member states, the Republic of Korea was able to have its representative attend the General Assembly as an observer and explain the Korean position to the member nations. Beginning with the 15th General Assembly session, the mass admission of the newly emerging Afro-Asian countries, which changed the balance of power between West and East, has forced the matter of the Korean question to enter a new phase.

The United Nations has continuously reaffirmed its objectives in Korea and maintained its physical presence in South Korea through UNCURK, thus making the Korean question a perennial issue in the General Assembly. Until 1972, the

20 Higgins, United Nations Peacekeeping, op. cit., pp. 290-310.

21 YBUN, 1953, pp. 127-128.

22 Stephen S. Goodspeed, The Nature and Function of International Organization, 2nd edition, New York, Oxford Univ. Press, 1967, pp. 260-262

23 Chong-Ki Choi, "The United Nations and Korea", KJIS, op. cit., p. 31.

24 U. N., Annual Report of the Secretary General on the Work of the Organization, 16 June $1957-15$ June 1958, GAOR: 13th Sess., Supp. no. 1 (A/3844), 1958, p. 26.

GAOR, 14thSess., no. 1 (A/4132), 1959, p. 27

25 United Nations Review (UNR), vol. 8, no. 1 (Jan. 1961), pp. 32-33. 
Republic of Korea, thanks to the support of its allies led by the United States, always had its way. Resolutions favoring the ROK position invariably carried.

A modification of South Korea's long-standing policy toward the United Nations annual debate on the Korean question was introduced in 1969. For two decades, the Korean question had been put on the agenda of each regular session of the United Nations General Assembly for "automatic" annual debate. Debates in the past yielded no tangible progress toward achieving Korean unfication.

The decisive blow to the ROK came in October 1971 when the United States failed to prevent the expulsion of the Nationalist Chinese government from the United Nations. From the ROK's perspective, Peking's entry into the United Nations posed a serious threat. The changing reality of United Nations politics was indeed a source of great concern and worry for the leaders of South Korea, and in order to avoid tedious debates concerning the Korean question, the ROK government, in close consultation with the United States, suspended its policy of automatic annual debate and decided to raise the issue during General Assembly debate only when the need might arise in a given session ${ }^{26}$. In fact, such a policy modification by the ROK did not prevent the Communist nations from bringing up resolutions concerning the "withdrawal of foreign troops" from Korea and the abolition of UNCURK.

By 1971 the Government of the ROK had reason to believe that only a new policy could eliminate the risk of a defeat at the 26th United Nations General Assembly. After a series of consultations with the Korean War Allies who supported its stand, the Government adopted a new tactic to prevent the Korean question from being taken up at the 26 th General Assembly session. The policy, in effect, was an attempt to postpone the issue for one year and to maintain the status quo. Justifications for the postponement of the Korean question at the United Nations were based upon the South-North Korean Red Cross Societies Talks which began in August, 197127. The new strategy carried the day when the United Nations General Assembly adopted a resolution calling for a postponement of the Korean debate. The same exercise was repeated at the $27 \mathrm{th}$ General Assembly session to postpone the Korean debate for still another year ${ }^{28}$.

In 1973, for the first time in its 25-year history, the DPRK established full diplomatic relations with several Western European nations, notably the five Nordic countries, Denmark, Norway, Sweden, Finland, and Iceland. Other countries with which North Korea established diplomatic relations in that same year were Argentina, Iran, Togo, Dahomey, Gambia, and Mauritius. On May 17, 1973, the World Health Organization (WHO), one of the specialized agencies of the United Nations, decided to admit North Korea as a member, brushing aside the plea of the representative from the Republic that dual representation for Korea might endanger the Korean dialogues and bring about the permanent division of Korea. As a result of its membership in the World Health Organization, North Korea obtained the status of permanent observer at the United Nations, and set up its observer mission in Geneva and New York.

\footnotetext{
26 The Chungang Ilbo, Sep. 27, 1969; Nov. 26, 1969.

The Dong-A Ilbo, Dec. 3, 1963.

Youngnok Koo, op. cit., p. 228.

27 United Nations, ORGA, Twenty-sixth Sess., General Committee, 193 meetings, 1971, pp. 72-75.

Youngnok Koo, op. cit., p. 229. and South.

28 Youngnok Koo, “Rationales of Korea's Foreign Policy”, Shin Dong-A, August 1973, p. 61.
} 
In the Republic of Korea's new unification policy, which is commonly called the June 23 Declaration, President Park Chung-Hee emphatically declared that the realization of the peaceful unification of the country was the "ultimate objective" of the ROK, and assured the people that he would "continue to exert unswerving effort" to achieve this ultimate objective. President Park called on North Korea: (1) to accept the principle of non-interference and non-aggression against each other in order to maintain peace in Korea, and (2) to continue the South-North Dialogue based on the South-North Joint Communique in order to see some concrete results at an early date. The President also declared that the ROK would "not be opposed" to becoming a member of the United Nations and other international organizations together with North Korea, if North Korea wishes ${ }^{29}$. This, he hastened to stress, did "not signify our recognition of North Korea as a state." Additionally, President Park said the ROK would open its doors to any country, regardless of ideology.

North Korea, branded President Park's proposal for simultaneous participation in the United Nations as a mischievous manoeuvre signifying South Korea's advocacy of two Koreas ${ }^{30}$. In rejecting Park's proposal, North Korea's Kim Il-Sung put forward a counter-proposal in a speech at a mass meeting welcoming the visit of Gustav Husak, General Secretary of the Czechoslovak Communist Party to Pyongyang. Reviving his earlier proposal for a confederation, Kim proposed that the two halves of Korea form a "Confederal State of Koryo" as a transitional step to reunification. Kim opposed the idea to enter the United Nations separately on the grounds that, "if the North and the South want to enter the United Nations before unification, they should enter as one state at least under the name of the Confederal Republic of Koryo ${ }^{31}$." He also reiterated Pyongyang's previous proposal for a multifaceted intercourse between the two Koreas and for the convening of a "great national assembly" of people representing all walks of life in the two sides.

The Republic of Korea rejected the idea of forming a confederation arguing that the proposed confederative system was a device with which North Korea was hoping to engineer the "National Liberation" of the South. South Korea also claimed that a confederal system was not a fitting model for the South and the North which have different ideologies and socio-economic systems ${ }^{32}$. North Korea then escalated its attacks on South Korea, accusing Seoul of plotting to perpetuate the division of Korea. Since then, although the dialogue has not been completely suspended, it has entered a very unproductive stage.

At the 28th United Nations General Assembly in the fall of 1973, a compromise to avoid a vote on the two rival draft resolutions on Korea was reached. The General Assembly agreement urged both South and North Korea to continue their dialogue to expediate the peaceful reunification of Korea. The only substantive decision in the consensus was dissolution of the U. N. Commission for the Unifica-

29 President Park Chung-Hee's Special Statement Regarding Foreign Policy for Pace and Unification, Seoul, Korea Information Service, Inc., 1973, pp. 29-34.

30 The People's Korea, Pyongyang, June 27, 1973.

31 Ibid., and The New York Times, June 24, 1973. Tongil Sinbo (Pyongyang), June 29, 1973.

32 The proposal for forming a Confederation of North and South Korea was first made by Kim Il-Sung on August 15, 1960.

Rodong Sinmun, August 16, 1960. The New York Times, August 15, 1960.

Pyong-choon Hahm, "Federalism: A Means for National Reunification of Korea", The Journal of Asiatic Studies, vol. XIII, no. 4 (Dec. 1970), p. 352.

Byung-Chul Koh, The Foreign Policy of North Korea, New York, Praeger, 1969, p. 134. 
tion and Rehabilitation of Korea ${ }^{33}$. It is important to note that the way in which the accord was reached signified the inevitable dependency of both North and South Korea on the major powers regarding the Korean question.

\section{Dissolution of UNCURK (First Committee)}

\begin{tabular}{cccccccccc}
\hline $\begin{array}{c}\text { G. A. } \\
\text { Session }\end{array}$ & Year & Yes & No & Abst. & Abs. & $\begin{array}{c}\text { Member } \\
\text { States }\end{array}$ & Yes & No $\begin{array}{c}\text { Abst. } \\
\text { Abs. }\end{array}$ \\
\hline 22 & 1967 & 24 & 60 & 29 & 9 & 122 & 19.6 & 49.1 & 31.1 \\
23 & 1968 & 27 & 68 & 27 & 4 & 126 & 21.4 & 53.9 & 24.3 \\
24 & 1969 & 30 & 65 & 27 & 4 & 126 & 23.5 & 51.5 & 24.6 \\
25 & 1970 & 32 & 64 & 26 & 5 & 127 & 25.2 & 50.4 & 24.4 \\
26 & 1971 & 68 & 25 & 22 & 15 & 131 & 51.9 & 19.0 & 28.2 \\
\hline
\end{tabular}

In 1974 the 29th General Assembly session urged continuation of the South-North talks and called on the Security Council to consider dissolution of the United Nations Command. The vote was 61 for, 43 against, and 31 abstaining. The present position of the government of the Republic of Korea appears to be that the Korean question should not be used as a means for confrontation and that the issue should be dealt with by the Koreans themselves in their own forums. The General Assembly at the same time rejected a pro-North Korean resolution by a vote of 48 to 48 . The General Assembly's recommendation on the Korean question, however, has so far failed to have any effect on the Security Council's action.

Number of Nations Supporting North Korea in the U. N.

(By Region and Year)

\begin{tabular}{lrrrrrrrrr}
\hline Region & 1966 & 1967 & 1968 & 1969 & 1970 & 1971 & 1972 & 1973 & 1974 \\
\hline Asia & 2 & 2 & 2 & 2 & 2 & 2 & 3 & 2 & 2 \\
Midle Eas (Arab) & 4 & 5 & 6 & 8 & 8 & 5 & 8 & 8 & 9 \\
Africa & 4 & 6 & 6 & 8 & 11 & 9 & 9 & 13 & 22 \\
(South of the Sahara) & 1 & 1 & 1 & 1 & 1 & 2 & 2 & 1 & 3 \\
Latin America & 0 & 0 & 0 & 0 & 0 & 0 & 3 & 1 & 1 \\
Western Europe & 10 & 10 & 10 & 10 & 10 & 10 & 10 & 10 & 11 \\
Eastern Europe & & & & & & & &
\end{tabular}

\begin{tabular}{lrrrrrrrrr}
\hline Region & 1966 & 1967 & 1968 & 1969 & 1970 & 1971 & 1972 & 1973 & 1974 \\
\hline (a) Total & 21 & 24 & 25 & 29 & 32 & 28 & 35 & 35 & 48 \\
(b) U. N. Membership & 122 & 122 & 126 & 126 & 127 & 131 & 132 & 135 & $137^{*}$ \\
(c) A as \% of B & 17.2 & 19.7 & 19.8 & 23.0 & 25.2 & 21.4 & 26.5 & 25.9 & 35.0 \\
\hline
\end{tabular}

* Membership was 138, but South Africa was excluded from voting.

In any event, both North and South Korea anticipate another diplomatic showdown at the 30th U. N. General Assembly on the Korean question, and are exerting their efforts to gain diplomatic support at the United Nations debate. Kim Il-Sung of North Korea, visited the PRC in late April, 1975, and travelled to five countries, including Rumania, Algeria, Moritius, Bulgaria, and Yugoslavia

33 Korea Newsreview, December 1, 1973, p. 6. 
from May 21 to June 10, 1975. The purposes of Kim's trip was to receive support from North Korea's allies on the Korean question during the U. N. General Assembly's consideration of its bid for a United Nations resolution calling for the withdrawal of the United Nations forces presence in South Korea. Furthermore, riding on the wave of Communist success in Indochina, and taking advantage of its psychological impact on some pro-West Southeast Asian countries, North Korea appears determined to attempt a full-scale diplomatic assault at this year's 30th United Nations General Assembly session, demanding the withdrawal of all foreign troops from South Korea ${ }^{34}$.

The United States, by agreement with South Korea, formally offered on June 27, 1975 to dissolve the U. N. Command in Korea next January 1 and replace it with U. S. and South Korean officers as parties to the 1953 Korean armistice agreement, providing that the Chinese and North Koreans consent ${ }^{35}$. The offer, in a letter to the U. N. Security Council, was aimed at heading off any demand from next fall's General Assembly that U. S. troops in South Korea under the U. N. flag be withdrawn. Such a request barely failed to be adopted last year. The U. S. and South Korean governments have argued that the status of the aggreement will be questionable if the U. S. officered U. N. Command, the party to the agreement, is dissolved without arrangements for a successor party. If the U. N. Command in Korea was dissolved, none of the U. S. troops in South Korea would fly the U. N. flag and the United States could argue that all 42,000 of them were entitled to stay there under a bilateral agreement. Even now, the Americans say only a handful of its forces are under U. N. Command.

North Korea and China have always demanded nothing less than the complete withdrawal of all foreign troops - meaning the American contingent of over 42,000 men in South Korea. The Western side will have priority in the voting on the Korean question and the contents of the resolution appear to be winning the widespread support of the 138 members of the United Nations.

Both North and South Korea are also trying to promote and expand their diplomatic recognition and hoping to win acceptance of their proposal at the United Nations General Assembly. As of June 20, 1975, North Korea had relations with 81 countries vis-à-vis 93 for South Korea. Among them 44 countries maintain contacts with both South and North Korea. Also North and South Korea's representation in International Organization are as follows ${ }^{36}$.

\section{Representation in International Organizations}

(As of June 20, 1975)

\begin{tabular}{lcccc}
\hline Int'l Organizations & $\begin{array}{c}(\mathrm{A}) \\
\text { South Korea }\end{array}$ & $\begin{array}{c}(\mathrm{B}) \\
\text { North Korea }\end{array}$ & Both South \& North & $\begin{array}{c}\text { B as } \% \\
\text { of A }\end{array}$ \\
\hline $\begin{array}{l}\text { U. N. Organizations } \\
\text { U. N. Specialized }\end{array}$ & 10 & 2 & 2 & 20 \\
$\begin{array}{l}\text { Agencies } \\
\text { Major Inter-govern- }\end{array}$ & 12 & 4 & 4 & 33.3 \\
$\begin{array}{c}\text { mental } \\
\text { Major NGO's }\end{array}$ & 27 & 3 & 2 & 11.1 \\
\hline Total & 229 & 119 & 42 & 51.9 \\
\hline
\end{tabular}

34 The Asahi Shimbun, June 12, 1975; May 30, 1975. The Mainichi Shimbun, June 12, 1975 ; June $13,1975$. The Yomiuri Shimbun, June 8, 1975.

35 The Korea Times, June 29, 1975.

36 Original Tabulation. 


\section{Problems of Admission For Membership}

The Republic of Korea applied for United Nations membership on January 19, 1949 and the North Korean regime followed suit on February 10, the same year. The United Nations Security Council voted on April 8, 1949, 9 to 2 to recommend the Republic of Korea's admission, but the Soviet Union vetoed it ${ }^{37}$. The Security Council at the same time voted down, 2 to 8 North Korea's application for admission ${ }^{38}$. Nevertheless, the ROK's application for membership was endorsed by the 4th United Nations General Assembly on December 22, 1949, in a resolution advising the Security Council to approve the Republic of Korea's admission into the world body ${ }^{39}$, but to date the ROK has not been granted membership in the UN.

South Korea's basic position on national unification and its overwhelming concern for security and peace was intensively elaborated in President Park's Declaration for Peace and Unification made on June 23, 1973. Point five of that Declaration says that "South Korea shall not object to its admittance into the United Nations together with North Korea, provided that it does not cause hindrance to national unification. Even before its admittance into the United Nations, South Korea shall not be opposed to North Korea also being invited at the time of the United Nations General Assembly deliberation of the Korean question.”

This Declaration indicates clearly that the United Nations policies of the Republic of Korea have been modified drastically in order to meet the changed international environment. This is a sign of maturity, realism and flexibility in the policies of South Korea ${ }^{40}$.

On the other side, North Korea has rejected the proposal on the grounds that it would perpetuate the division of Korea, and Kim Il-Sung has made the following counterproposal: North Korea would not enter the United Nations separately, and that if the South and the North want to enter the United Nations before unification, they should enter as one state at least under the name of the Confederal Republic of Koryo ${ }^{41}$.

These are the basic differences in their attitudes toward the United Nations. Almost every year the two opposing parties have been arguing their positions in the world forum and the deliberation intensified when North Korea began directly participating in the discussions following the 28th session in 1973. Issues in the disputes are procedural and legal as well as substantive and political.

Until the end of the 1950's there were no difficulties for the Republic of Korea on the deliberation of the Korean question. The Republic of Korea was recognized by the world forum to be the only lawful government having effective control and jurisdiction over Korea ${ }^{42}$. The changed situations in the world forum in the early part of 1960's was manipulated by North Korea and its camp and arguments for inviting both parties, the South as well as the North, for the deliberation of Korean question have begun to mobilize the sympathy of the new-comers and non-aligned powers in the United Nations. The problem of competence and

37 U. N., Repertory of Practice of United Nations Organs, vol. 1, op. cit., p. 169, para. 9, footnote 5.

38 Ibid., p. 171, para. 16.

39 Jae-Seung Woo, "Korea and the United Nations, "The Korean Journal of International Studies, vol. V. no. 4 (1974), p. 10.

41 Rodong Shinmun, June 24, 1973. The Korea Times, June 24, 1973. The New York Times, June $24,1973$.

42 UNGA Resolution 195 (III), December 12, 1948. 
authority of the United Nations toward Korean unification still remains unsettled although North Korea obtained observer status in the General Assembly in 1973. Even though North Korea is represented as on observer at the United Nations and is making every effort to enter the United Nations specialized agencies separately (WHO, UPU, UNCTAD, and UNESCO, etc.), and seeks to. conclude bilateral diplomatic ties with countries that maintain diplomatic ties with South Korea, North Korea is vehemently opposed to the dual membership in the United Nations proposed by President Park in his Seven Point Declaration for Peace and Unification on June 23, 1973.

The Republic of Korea believes that dual membership in the United Nations would not become a hindrance to national unification. If South and North so agree they can be united any time they wish in spite of separate memberships in the U. N., dual membership is not meant to freeze the division of the status quo. What the Republic of Korea really aims at is to bring North Korea into the world forum and to keep it within the bounds of international law, thus hoping that peace can be maintained on the Korea peninsula.

North Korea's rationale in rejecting dual membership is that this course of action would perpetuate the national division and signify formal acceptance of a divided nation. North Korea's allegations are:

(1) If North and South Korea enter the United Nations separately, Korea will be recognized as two states internationally and the division of Korea will be fixed indefinetely; (2) If Korea is forcibly split into two states, it will create permanent tension and increase the likelihood of war; (3) South Korea is not entitled to enter the United Nations because the South Korean regime is a bogus regime and South Korea is nothing but a colony and military base of a foreign country; (4) Simultaneous admission is a scheme to camouflage the imperialist's old method of colonial domination of "divide and rule"; (5) North Korea's entry into the U. N. specialized agencies is for the purpose of technical and practical cooperation among all countries; (6) The German case is different from the Korean case; (7) The question of admission of every country to the U.N. should not be regarded as a means of solving the internal affairs of a nation ${ }^{43}$.

In addition to her repeated applications for U. N. membership in the past, North Korea has recently secured status of the permanent observer in the U. N. along with the South ${ }^{44}$. By seeking and achieving representative status in many of the U. N. specialized agencies where the South already has representatives, the North is de facto recognizing and accepting the idea of dual representation although at the same time she is publicly insisting that if the South and the North want to enter the United Nations before unification, they should enter as one state or at least under the name of the Confederal Republic of Koryo ${ }^{45}$. They publicly reject dual membership on the grounds that this course of action would perpetuate national admittance into the United Nations. This contradiction indicates the flexibility of division and signify formal acceptance of divided nation.

How does North Korea justify its entry into WHO and a series of bilateral diplomatic ties with countries having relations with South Korea?

North Korea explains that „such diplomatic activity will serve to strengthen international support for North Korean policy without entailing a commitment to the

43 The Journal of Korean Affairs, vol. III, no. 4 (Jan. 1974), pp. 69-74.

44 U. N., Repertory of Practice of United Nations Organs, vol. 1, 1955, op. cit.; pp. 169-171.

45 The New York Times, June 24, 1973. 
idea of two Koreas ${ }^{46}$. They further say that the U. N. specialized agencies are non-political. Apparently, this is a contradiction of their objection to mutual admittance into the United Nations. This contradiction indicates the flexibility of their integrative scheme for eventual revolution in the South.

\section{Conclusion}

The present Korean environment requires the introduction of new policies which will break through the vicious circle of tensions created by mental blocks and psychological barriers, which are intrinsically derived from the ideological conflict and have thus far prevented either party from correctly perceiving the other and from acting on this insight.

South Korea has charged that, "North Korea has never changed its strategic objective of communizing South Korea", and that "their demand [to remove the $\mathrm{UNC}$ ] is designed to bring about a military vacuum in the Republic of Korea".

The South also claimed that the dissolution of the UNC would eliminate a principle party to the Armistice Agreement and virtually invalidate it. Therefore continous operation of the United Nations Command in Korea was seen as essential and vital to national security ${ }^{47}$.

The recently announced proposal to the coming 30th General Assembly by the Republic of Korea and the United States to dissolve the U. N. Command is regarded a compromise proposal which would satisfy North Korean demands for the dissolution of the U. N. Command while at the same time replacing them (by U. S. forces) with a successor party capable of preserving the Armistice Agreement. From North Korea's point of view, the United Nations forum provides a convenient place to condemn "the U. S. imperialists" activities in Korea before the sympathetic audience of the Third World. This position also enables them to enhance their international status and helps to promote their policy of engaging in economic and scientific-technical exchanges which are badly needed by their ailing economy. In addition, the presence of the United Nations Command in Korea is a convenient target for their domestic propaganda activities, allowing them to maintain a revolutionary air and consolidate national unity by picturing the South as "occupied" by foreign troops, thus challenging the authority and even the legitimacy of the Republic of Korea. This is precisely why Pyongyang proposed to conclude a peace agreement directly with the United States ${ }^{48}$.

Kim Il-Sung's speech at his reception in Peking on April 18, 1975, emphasized that "if the revolution of the people occurred in South Korea, North Korea would strongly support such a revolution and we can get the territory of reunification and lose the military demarcation line ${ }^{49}$ ".

Both Seoul and Pyongyang are now concentrating their all-out efforts on diplomatic competition in the international arena, and a South-North show-down at the forthcoming United Nations General Assembly seems inevitable.

\footnotetext{
46 The Journal of Korean Affairs, vol. III, no. 4 (Jan. 1974), pp. 69-78.

47 See the text of speech made by the chief U. N. delegate at the 28th session of the General Assembly, The Korea Times, November 16, 1973.

48 The New York Times, March 25 and 26, 1974. Jae-seung Woo, op. cit., p. 16.

49 Rodong Shinmun, April 19, 1975. The Korea Times, April 19, 1975.
} 
South Korea has gradually come to accept a step-by-step approach to national unification, placing high priority on eliminating the dangers of war, whereas North Korea adheres to a radical approach to national reunification with an emphasis on the solution of military and political problems first and foremost. These contending theories would seem to indicate that the process of unification will be an extended one, if it is to take place at all.

In order to make the initial step toward peaceful unification this vicious circle may be reversed by generating a process of threat reduction. Reduction of tension and of a capacity for violence is hence the primary need to be fulfilled. At the next stage both sides will have to open communications and negotiations for resolving their mutual hostilities. Communications will become an essential element in the bargaining process between both actors in the conflict ${ }^{50}$.

Realistically considering the existing differences in the social, political and ideological systems of both sides, I believe that the peaceful reunification of Korea is possible only when a durable peace has been established on the peninsula, and not the other way around as is persistently claimed by the North. Peace cannot be achieved without the unfailing will and determination of both parties to pursue it. Reducing tensions through dialogues, constant reaffirmation of faith in the dialogues and legitimization of the existing peace system are some of the more realistic and most essential patterns of approach to conflict resolution. This fact was stressed in the United Nations consensus statement which called for a continuation of the dialogue and a widening of exchanges and cooperation between the South and the North.

Both South and North Korea must remember the spirit and principles of the July 4, 1972 Joint Communiqué which they signed. Peace must be maintained on the Korean peninsula by all means, and the South and the North should never interfere with the other's internal affairs nor commit aggression against the other, thus allowing for the integration of peaceful coexistance between both systems. This reduction of tension and hostilities is the initial step toward the promotion of mutual relations, peaceful coexistance, and the unification of Korea.

50 Yong-pil Rhee. "The Gradual Search for the Sequential Steps toward Korean Unification", The Korean Journal of International Studies, vol. VI, no. 3 (1975), p. 47. 